Журнал «Герспективитаінноваціїнауки»

(Серія«Гедагогіка»), Серія«ГТихологія», Серія «Медицина»

№5(5) 2021

УДК 615.82

https://doi.org/10.52058/2786-4952 -2021-5(5)-890-901

Недоступ Ілля Володимирович студент, кафедра фізичної терапії, Міжнародний науково-технічний університет імені академіка Юрія Бугая, Магнітогорський провулок, 3, Київ, 02000, тел.: (044) 291-50-53, e-mail: meracrec@gmail.com, https://orcid.org/0000-0003-0520-5753

\title{
ОСОБЛИВОСТІ ПРОВЕДЕННЯ МАСАЖУ ПРИ ВИВИХУ ПЛЕЧОВОГО СУГЛОБА
}

Анотація. Ушкодження верхніх кінцівок $є$ дуже розповсюдженим видом травми. А процес їх лікування, повинен включати не тільки хірургічну допомогу хворому а й потребує залучення методів і засобів фізичної терапії для повного відновлення організму після травми. Плечовий суглоб є одним із найбільш рухливих суглобів в організмі. Завдяки рухливості даного суглоба можливим $\epsilon$ піднімання рук і заведення їх за голову. Процес відновлення $\epsilon$ досить тривалим і включає послідовні етапи, які містять комплекс засобів фізичної терапії розроблений індивідуально, в залежності від віку хворого, стану ушкодженої кінцівки, особливостей лікування i одужання. Проте, класично до кожної окремої програми фізичної терапії включається масаж, який вважається провідним засобом фізичної терапії у відновленні після вивиху плечового суглоба. Статтю присвячено дослідженню актуального у фізичній терапії питання - доцільності застосування та особливостям проведення масажу при вивиху плечового суглоба. Оскільки вивих плечового суглоба $є$ досить розповсюдженим видом травми, процес реабілітації потребує комплексного підходу із обов'язковим включенням до програми заходів масажних процедур. Відповідно до поставлених завдань дослідження розкривається сутність вивиху плечового суглоба, його особливості, та підходи до лікування даного виду травми. Зауважується на важливому значенні фізичної терапії в ході лікування пацієнтів з даним видом травми. Відтак, у статті досліджено основні сучасні підходи до побудови програм фізичної терапії при вивиху плечового суглоба і місце масажу в даних програмах. Зауважується на виключній ролі масажу у лікуванні різних травм, включаючи травми плечового суглоба. У статті також визначаються етапи проведення програм фізичної терапії при вивиху плечового суглоба. На основі визначених етапів автор відзначає необхідність застосування різних видів масажу які відповідають періодам програми фізичної терапії.

Ключові слова: фізична терапія, масаж, самомасаж, вивих плечового суглоба, травма. 
Nedostup Illia Volodymyrovych Student of the International Scientific and Technical University Yuriy Bugaya Academician name Department of Physical Therapy Magnitogorsky Lane, 3, Kyiv, 02000, tel.: (044) 291-50-53, e-mail: meracrec@gmail.com, https://orcid.org/0000-0003-0520-5753

\section{FEATURES OF MASSAGE WHEN PLAYING A SHOULDER JOINT}

Abstract. The damage to the upper extremities is a very widespread injury. And
the process of their treatment should include not only surgical assistance to the full restoration of the body after an injury. The recovery process is quite prolonged and includes successive stages that contain a complex of physical therapy techniques are designed individually, depending on the age of the patient, the state of the damaged limb, the peculiarities of treatment and recovery. However, classically, a massage is included in each individual program of physical therapy, which is considered to be a leading means of physical therapy in recovering after the shoulder joint. Massage and self-massage contribute to the restoration of mobility in the shoulder joint, reduce pain sensations, increase the overall tone of the body. Therefore, the study of the features of massage during the shoulder joint is important and relevant theme.The article is devoted to the study of urgent physical therapy in physical therapy - the expediency of the use and peculiarities of massage in dislocation of the shoulder joint. Since the winning shoulder joint is a rather widespread injury, the rehabilitation process requires a comprehensive approach to the mandatory inclusion program for massage procedures. In accordance with the tasks of the study, the essence of the shoulder joint is revealed, its features, and approaches to the treatment of this type of injury. It is noted on the important meaning of physical therapy in the treatment of patients with a given kind of injury. Therefore, the article investigates the main modern approaches to building physical therapy programs in the welcome of the shoulder joint and the place of massage in these programs. Notes on the exclusive role of massage in the treatment of various injuries, including shoulder joint injuries. The article also determines the stages of conducting physical therapy programs during the shoulder joint. On the basis of certain stages, the author notes the need for various types of massages that meet the periods of physical therapy program.

Keywords: physical therapy, massage, self-massage, dislocation of the shoulder joint, trauma.

Постановка проблеми. Ушкодження верхніх кінцівок $\epsilon$ дуже розповсюдженим видом травми. А процес їх лікування, повинен включати не тільки хірургічну допомогу хворому а й потребує залучення методів і засобів фізичної терапії для повного відновлення організму після травми. Процес відновлення $є$ досить тривалим і включає послідовні етапи, які містять комплекс засобів фізичної терапії розроблений індивідуально, в залежності 
Журнал «Герспективитаінноваціїнауки»

(Серія«Гедагогіка», Серія«ГЕихологія», Серія «Медицин»

№5(5) 2021

від віку хворого, стану ушкодженої кінцівки, особливостей лікування i одужання. Проте, класично до кожної окремої програми фізичної терапії включається масаж, який вважається провідним засобом фізичної терапії у відновленні після вивиху плечового суглоба. Масаж і самомасаж сприяють відновленню рухливості у плечовому суглобі, зменшують больові відчуття, підвищують загальний тонус організму. Тому, вивчення особливостей проведення масажу при вивиху плечового суглоба $є$ важливою та актуальною темою.

Метою роботи $є$ дослідження особливостей проведення масажу при вивиху плечового суглоба.

\section{Завдання дослідження:}

1. Розглянути особливостівивиху плечового суглоба;

2. Визначити сучасні підходи до організації процесу відновлення організму після вивиху плечового суглоба;

3. Окреслити особливості проведення масажу при вивиху плечового суглоба.

Виклад основного матеріалу. Плечовий суглоб $є$ одним із найбільш рухливих суглобів в організмі. Завдяки рухливості даного суглоба можливим $\epsilon$ піднімання рук і заведення їх за голову.

Плечовий суглоб утворених двома кістками: плечовою і лопатковою. Головка, тобто верхня частина плечової кістки, стикається із суглобовою западиною лопатки. Головка утримується в суглобі завдяки валику, суглобовій губі.

Суглоб оточений капсулою, що складається із сполучної тканини, тобто зв'язок. Вони фіксують верхню частину плечової кістки в правильному положенні у відношенні до западини лопатки. Також плечовий суглоб оточують м'язи і сухожилля [2].

Плечовий суглоб покликаний виконувати велику кількість рухів, тобто піддається постійному навантаженню. Вплив зовнішньої сили, наприклад, падіння, може зумовити зсув - тобто зміну положення верхньої частини плечової кістки у відношенні до западини лопатки.

Залежно від того в якому напрямку відбувся зсув голівки плечової кістки, розрізняють декілька видів вивихів: Вивих вважається переднім, якщо зміщення головки відбулося вперед. Зсув може супроводжуватися пошкодженням суглобової губи, відривом. Такий вид травми називають пошкодженням Банкарта. Ще одне неприємне ускладнення - розрив суглобової капсули. Передні вивихи трапляються під час занять спортом, при повторенні амплітудних рухів плечем, кидках, падінні на відведену назад пряму руку або на плече. Вивих що виник у випадку зміщення головки кістки плеча назад, називають заднім вивихом. Такі травми відбуваються значно рідше, ніж передні вивихи. Вивих може виникнути від удару в плече, при цьому може відірватися суглобова губа. При нижньому вивиху головки плечової кістки зсувається у напрямку вниз. Такий вид травма часто 
трапляється під час занять на турніку. Це найменш поширений вид травми плеча. Діагностувати нижній вивих дуже просто - людина не може опустити руку [8].

Якщо вивих в плечовому суглобі відбувся вперше, вивих називають первинним. Причиною первинного вивиху зазвичай стає травма.

Коли плечова кістка починає «гуляти» в плечовому суглобі, говорять про «звичний вивих». Стан стає хронічним. Більшість пацієнтів зі звичним вивихом плеча колись мали ушкодження плечового суглоба. Травма супроводжувалася відривом суглобової губи, хряща, який фіксує голівку плечової кістки.

Вправлення вивиху проводять декількома методами - відкритим і закритим:

1. Закритий метод - безопераційний. У суглоб пацієнта вводиться знеболюючий препарат, після чого травматолог вправляє головку кістки, ставлячи ii на місце. Якщо 3 моменту травми пройшло більше 24 годин, лікарю складніше вправити вивих, оскільки м'язи вже скоротилися. Тоді вправляння відбувається під анестезією із застосуванням міорелаксантів.

2. Відкритий спосіб передбачає хірургічне втручання. Хірургічна операція - надійний спосіб позбутися від вивихів які часто повторюються. Під час операції лікар розкриває і вправляє суглоб пацієнта. Існує велика кількість різних операцій, тому тип хірургічного втручання залежить від конкретного індивідуального випадку [4].

Реабілітаційні заходи при травматичному вивиху плеча починають 3 перших днів після вправляння. Програма реабілітації складається з трьох періодів: 1. Іммобілізаційний період (3-4 тижні), 2. Постіммобілізаційний період (до 2,5-3 місяців), 3. Відновний період (до 6 місяців після травми).

Іммобілізаційний період (3-4 тижні),

Метою періоду іммобілізації $\epsilon$ створення оптимальних умов для формування міцного сполучно-тканинного рубця, профілактика гіпотрофії м’язів плечового поясу шляхом активізації функції м'язів плеча i пошкодженої кінцівки.

У перші дні після травми, пацієнт виконує активні рухи здоровою рукою як в суглобах кисті так і пальцями травмованої руки. Робляться спроби рухів в ліктьовому суглобі (згинання, розгинання, пронація і супінація), а також в плечовому суглобі (згинання, приведення, розгинання плеча). 3 10-14 дня хворому пропонується піднімати лікоть і повертати плече назовні. 3 14-20 дня, не знімаючи шини, виконують активні рухи в ліктьовому суглобі. 321 дня приступають до активно-полегшених рухів в плечовому суглобі у горизонтальній площині.

Масаж, як правило, починають через 2-3 тижні після травми. Процедуру проводять в положенні сидячи, не знімаючи шини. Виконують прийоми поглажування і розтирання надпліччя і області дельтоподібного м'яза. У разі відсутності болю застосовують стьобання і поплескування. 
Показанням до раннього застосування масажу уже в період іммобілізації $є$ ушкодження плечового сплетення, що супроводжує вивих плеча. Методика організації процедури масажу при цьому схожа на раніше описану, i доповнюється вібраційним масажем паравертебральних точок $\mathrm{C}_{2}-\mathrm{D}_{3}$, по ходу плечового сплетення і місць прикріплення дельтоподібного м'яза. При більш значному ураженні плечового сплетення проводиться вібрація по ходу основних нервових стовбурів травмованої руки, точок виходу (поверхневого розташування) периферичних нервів, а при появі ознак відновлення їх функції - місць прикріплення м'язів сухожиль і рухових точок м'язів, іннервацію яких вони здійснюють [1].

Важливе місце серед засобів реабілітації, які використовуються в період іммобілізації при травматичних вивихах плеча, займає фізіотерапія. Так, для зменшення набряку м'яких тканин призначається СВЧ або УВЧ-терапія або магнітотерапія на область плечового суглоба через гіпсову пов'язку. При вираженому больовому синдромі проводиться електронейроаналгезія, електрофорез місцевих анестетиків або рефлексотерапія. Після купування болю, для профілактики гіпотрофії м'язів і активізації місцевого кровотоку використовується ритмічна електростимуляція навколосуглобових м'язів.

Зазначений комплекс реабілітаційних заходів, що проводяться в період іммобілізації при вивихах плеча, дозволяе значно зменшити виражену гіпотрофію м'язів, що покращує умови для компенсації функції плечового суглоба [6].

\section{Постіммобілізачійний період (до 2,5-3 місяців)}

Із припиненням іммобілізації починається найбільш відповідальний період відновного процесу. Його метою є відновлення стабільності плечового суглоба і амплітуди руху у плечовому суглобі. Комплекс реабілітаційних заходів включає лікувальну гімнастику, масаж, трудотерапію, тренування побутових навичок, гідрокінезіотерапією і фізіотерапію. В окремих випадках включаються методи механотерапії.

Відповідно до фази структурної та функціональної перебудови тканин плечового суглоба у постіммобілізаційному періоді виділяються два етапи:

- ранній постіммобілізаційний (до 1,5 місяців після травми) та

- пізній постіммобілізаційний (до 2,5-3 місяців) [2].

Для спортсменів і осіб, професійна діяльність яких пов'язана із великим функціональним навантаженням плечового суглобу, виділяється додатковий період - задля відновлення спеціальних і професійних рухових навичок (до 6 місяців).

Завданням раннього постіммобілізаційного етапу є усунення міогенної контрактури плечового суглоба, без порушення цілісності посттравматичного рубця, що сформувався.

Провідну роль у комплексі реабілітаційних заходів на даному етапі продовжує грати лікувальна гімнастика. Використовуються вихідні положення, які запобігають розтягненню капсули плечового суглобу - лежачи 
на спині, лежачи на здоровому боці, сидячи і стоячи, підтримуючи уражену руку здоровою або уклавши їі на широку косинку, сидячи 3 валиком в пахвовій області, сидячи, спираючись зігнутим ліктем або передпліччям хворий руки на стегно або на площину, на четвереньках і стоячи на колінах, спираючись грудьми на підставку [5].

Більш широкі можливості для застосування в ранньому постіммобілізаційному періоді має масаж. Зазначимо, що в перші дні після припинення іммобілізації спостерігаються значні больові відчуття при виконанні рухів і рефлекторному напруженні м'язів. Для їх усунення проводиться 1-2 процедури підводного струменевого масажу області плеча i надпліччя 3 невисоким тиском водного струменя і 3 додаванням повітря. 3 цією ж метою використовується ручний масаж під водою і масаж душовою установкою. Всі перераховані процедури закінчують виконанням вільних активних рухів в плечовому і ліктьовому суглобах у воді. Більше число процедур гідромасажу $\epsilon$ небажаним, оскільки приводить до надмірного розслаблення м'язів і зниження стабільності суглоба, що супроводжується розтягненням капсули і відновленням болюв ураженій області.

Метою пізнього постіммобілізаційного етапу $є$ повне відновлення ушкодженої руки. Він триває до 2,5-3 місяців після травми. Для нього характерним $\epsilon$ зниження функціональних можливостей надостного, підостного і малого круглого м'язів (коротких ротаторів плеча), що особливо яскраво проявляється в положенні відведення плеча. Це викликає порушення стереотипу рухів верхньої кінцівки і, перш за все, їі відведення від $60^{\circ}$ до $90^{\circ}$.

У зв'язку з цим, провідним завданням пізнього постіммобілізаційного етапу $\epsilon$ відновлення м'язового балансу - координації рухів пошкодженої руки. Крім того, значна увага приділяється збільшенню витривалості до тривалого статичного i динамічного навантаження м'язів плеча i поясу верхніх кінцівок, а також на відновлення професійних рухових навичок [3].

Таким чином, як ми можемо бачити методи масажу задіюються на всіх етапах відновного процесу після вивиху плечового суглоба. Важливо відзначити що масаж у відновному процесі після вивиху плечового суглоба має ряд особливостей. У кожному періоді відновного лікування застосовуються різні методи і прийому масажу. Проте, у загальному, цілі масажу у відновному процесі після вивиху плечового суглоба полягають в наступному: Повернення рухливості плечового поясу; Усунення втоми i затиснення; Усунення головного болю; Зміцнення сухожилля; Сприяння загоюванню рани; Покращення м'язового тонусу; Усунення болю в області суглоба; Розслаблення м'язового каркасу [7].

Починати курс масажу рекомендується ще в доопераційному періоді. Це особливо важливо для спортсменів, які вже перенесли певну кількість вивихів.

Використання масажу в реабілітації звичного вивиху плечового суглобу при оперативному лікуванні складається з чотирьох періодів: доопераційного, періоду іммобілізації, постіммобілізаційного і відновного (спортивно- 
Журнал«Герспективитаінновації наукиљ

(Серія «Гедагогіка», Серія «Гиихологія», Серія«Медицина»

NN5(5) 2021

відновного).

Розглянемо особливості проведення масажуу доопераційний період.

Метою масажних процедур, які виконують у даному періоді, є зміцнення м’язів плечового поясу, поліпшення їх трофіки. Масаж починають проводити за 3-5 тижнів до операції, бажано щодня, його тривалість - 15-20 хв.

Окрім масажу у доопераційний період хворі займаються лікувальною фізкультурою, відвідують басейн. Масаж можна проводити як до фізичних вправ, так і після них. Найбільш ефективним він $\epsilon$ при проведенні двох сеансів масажу в день, тобто перед заняттями лікувальною фізкультурою i після них, через 2-3 год.

Застосовують наступні види масажу:

1. Масаж надпліччя. При масажі надпліччя (верхніх пучків трапецієподібних м'язів) найбільш зручне положення хворого - сидячи на стільці, руки пацієнта опущені або лежать на стегнах, спина i шия розслаблені. Масаж починають 3 поперемінного поглажування в напрямку від волосяного покриву голови до плечового суглобу (4-6 разів), потім виконують вижимання ребром долоні (3-5 разів), розминання подвійне кільцеве і ребром долоні 4-5 разів [3].

Масаж на стороні вивихнутого і здорового плеча проводять за однією методикою. Комплекс повторюють 3-4 рази.

2. Масаж грудей. Масаж починають із здоровогобоку. Якщо масаж грудей проводиться з правого боку, то положення масажиста - злівогобоку. Одну руку він встановлює з боку спини в області лопатки, а іншою виконує масаж: прямолінійні поглажування від реберного кута вгору до пахви (3-5 разів), вижимання ребром долоні (3-5 разів), ординарне розминання $\mathrm{i}$ розминання фалангами пальців, зігнутих в кулак (3-4 рази кожний прийом). Закінчують потряхуванням та поглажуванням. Комплекс проводять 1-2 рази. Масаж грудей з боку травмованого плеча і з боку здорового виконують за однією методикою. Комплекс повторюють 3-4 рази.

3. Масаж спини. Пацієнт знаходиться у сидячому положення, рука з боку частини спини яку масажують лежить настегні. Масаж починають з боку здорової руки. Одну руку масажист накладає на дальню сторону грудей пацієнта, а іншою на цій же стороні проводить масаж: прямолінійні поглажування (3-4 рази), вижимання ребром долоні (4-6разів), розминка основою і ребром долоні (по 3-5 разів). Закінчують поглажуванням. Весь комплекс повторюють 2-3 рази. За такою ж методикою масажується спина 3 боку травмованої кінцівки, але комплекс прийомів повторюється 4-6 разів [8].

4. Масаж плеча. Найбільш зручно виконувати масаж 3 вихідного положення пацієнта на спині. Масажувати слід в п’яти положеннях. Масаж плеча повинен бути жорстким, зміцнюючим.

5. Масаж передпліччя. Необхідно підкреслити, що особливу увагу слід приділяти дельтоподібному, триголовому і двоголовому м'язам. Тривалість масажу руки не більше 8 хв. 
Методика масажу в період іммобілізації також має ряд визначних особливостей. Другий період реабілітації починається відразу після операції і триває весь час, поки травмована кінцівка фіксована гіпсовою пов'язкою.

На другу добу після операції призначається масаж, який проводиться в палаті. При поліпшенні загального стану пацієнт може відвідувати масажний кабінет.

Масаж починають 3 трапецієподібних м'язів (підпліччя) на здоровій стороні. Виконують поперемінне поглажування (6-7 разів), вижимання ребром долоні (6-7 разів), розминання ребром долоні (6-8 разів), поглажування (5-6 разів), вижимання (2-3 рази), подвійне кільцеве розминання (4-6 разів), вижимання ребром долоні (3-4 рази), поглажування (3-5 разів) [4].

У період іммобілізації методика масажу в області спини виконується глибше і жорсткіше, ніж в першому періоді. Початкове положення хворого сидячи. Починають масаж з боку здорової руки.

Застосовують поглажування (4-6 разів), вижимання ребром долоні (6-8 разів), розминання ребром долоні і основою долоні (по 4-5 разів кожне), вижимання (3-4 рази), розминання фалангами пальцем, зігнутих в кулак (4-6 разів), вижимання (3-4 рази), поглажування (3-4 рази), розминання основою долоні (5-7 разів), вижимання (3-4 рази). Весь комплекс повторюють 3-4 рази. За такою ж методикою масажується спина з боку оперованого плеча, але кількість повторень збільшується.

На найширших м'язах спини 3 боку здорової кінцівки застосовують: поглажування (3-4 рази), вижимання (3-4 рази), ординарне розминання (5-7 разів), поштовхи (2-3 рази), вижимання (2-4 рази), ординарне розминання (3- 4 рази), закінчують потряхуванням і поглажуванням [2].

У перші дні після операції (залежно від стану хворого) рекомендується проведення масажу на найширших м'язах спини з боку оперованої кінцівки. При цьому у пацієнта не повинно виникати больових відчуттів.

Масаж грудей починають зі здорової сторони. Застосовують: прямолінійні поглажування (4-5 разів), поперечне вижимання (3-5 разів), ординарне розминання (4-5 разів), вижимання (3-4 рази), розминання фалангами пальців, зігнутих в кулак (3-5 разів), ординарне розминання (4-7 разів), поштовхи і поглажування (по 2-3 рази). Весь комплекс прийомів повторюють 3-4 рази.

На грудях зісторони прооперованої кінцівки методика масажу є такою ж самою, проте необхідно враховувати стан хворого. Якщо у пацієнта виникає біль в плечовому суглобі, масаж проводиться в більш легкій формі. Комплекс прийомів повторюється до 6 разів. У міру поліпшення стану хворого сила масажу повинна зростати.

Якщо хворий може без особливої напруги покласти передпліччя на масажний стіл, то це $є$ найкращим положенням не тільки для масажу передпліччя, a i для майбутнього масажу всієї кінцівки. Застосовуються 
Журнал«Герспективита іновації наукиљ

(Серія «Педагогіка», Серія«Птихологія», Серія«Медицина»

№5(5) 2021

прийоми: поглажування (3-5 разів), вижимання (3-5 разів), розминання фалангами пальців, зігнутих в кулак (4-5разів), вижимання (3-4 рази), розминання ребром долоні (3-4 рази), вижимання (2-3 рази), розминання подушечками чотирьох пальців (3-4 рази). Закінчують поглажуванням (2-4 рази) [5].

Масаж проводиться 2-3 рази на день. Перші сеанси - по12-15 хв, а на наступні сеанси щодня можна додавати по хвилині, збільшуючи час масажу до 20-25 хв.

Схема проведення сеансів (методика) повинна поступово змінюватися: час масажу на стороні здорової руки має скорочуватися, на стороні прооперованої- збільшуватися.

Третій період реабілітації, постіммобілізаційний, через 3-4 місяці після операції, характеризується вираженою тугорухливістю прооперованого суглоба, слабкістю м’язів, зниженням загальної працездатності пацієнта.

У цей час вирішується основне завдання: зміцнення груп м'язів плечового суглоба. Відразу ж після зняття гіпсової пов'язки призначається масаж всієї кінцівки. Протягом всього періоду реабілітації виконується кілька курсів масажу по 12-15 сеансів, з перервою 8-12 днів.

Перші кілька днів після зняття гіпсової пов'язки прооперована кінцівка підвішується на косинці, щоб запобігти розтягненню капсули плечового суглоба. Масаж слід проводити в таких вихідних положеннях, щоб кінцівка була надійно зафіксована масажистом, тобто в положенні лежачи на спині або сидячи, коли кінцівка передпліччям лежить на масажному столі або стегні пацієнта [3].

На початку третього періоду, коли м'язи ослаблені, а амплітуда згинання, відведення тощо, в плечовому суглобі обмежена, застосовується масаж для зміцнення м'язів, усунення наявної контрактури i відновлення колишньої гнучкості. Для того щоб курс проведеного масажу був найбільш ефективним, необхідно знати розташування м’язів, які відносяться до плечового суглобу, i їх функції.

Знання функцій того чи іншого м’яза, місця його прикріплення знадобиться і тоді, коли з метою зміцнення плечового суглоба і підвищення гнучкості будуть застосовуватися рухи: активні, пасивні та з опором. Всі рухи повинні виконуватися легко, без ривків, це зауваження треба особливо врахувати при виконанні пасивних рухів.

На даному періоді масаж плечового суглобапочинають 3 верхньої частини здорової кінцівки. Пацієнт знаходиться у положенні сидячи. Виконуються поглажування (3-4 рази), вижимання ребром долоні (5-6 разів), розминання основою долоні (4-5 разів), фалангами пальців, зігнутих в кулак (7-8 разів), вижимання (3-4 рази), розминання підставою основою долоні i подушечками чотирьох пальців (по 3-4 рази кожен). Потім масажується найширший м'яз спини: вижимання (4-5 разів), ординарне розминання (3-4 рази), поштовхи (2-3 рази), вижимання (2-3 рази), ординарне розминання 
(4-5 разів), поштовхи (2 - 3 рази). Закінчують масаж поглажуванням найширшого м'яза спини. Комплекс повторюють 3-4 рази [6].

Виконуючи масаж грудей, після двох-трьох проводять вижимання (3-4 рази), ординарне розминання (3-4 рази), поштовхи (2-3 рази), повторюють ординарне розминання, розминку подушечками чотирьох пальців (по 3-4 рази), поштовхи (2-3 рази) і повторюють вижимання (3-4 рази), ординарне розминання основою долоні (по 3-4 рази). Закінчують потряхуванням i поглажуванням (по 2 рази). Весь комплекс прийомів повторюється 3 рази. За такою ж методикою проводиться масаж і з боку прооперованого плеча.

Масаж надпліччяпочинають 3 оперованого плеча. Виконуються поглажування в напрямку від волосяного покриву голови з верхніх пучків трапецієподібного м'яза до дельтоподібного м'яза (5-8разів), вижимання ребром долоні (2-3 рази), розминання ребром долоні і ординарне (по 2-3 рази кожне), поглажування (2-3 рази). Весь комплекс повторюють 2-3 рази, після чого переходять на здорову сторону.

Виконуються поглажування (1-2 рази), вижимання ребром долоні (2-3 рази), розминання ребром долоні (3-4 рази), подвійне кільцеве (3-4 рази), ребром долоні (3-4 рази), поглажування (2-3 рази). Після цього знову масажується надпліччя 3 боку прооперованої кінцівки. Методика масажу зберігається, але в залежності від самопочуття хворого глибина і сила масажу можуть змінюватися. Весь комплекс повторяють 4-5разів [8].

Після такої попередньої підготовки м'язів плечового суглоба, що беруть участь в його рухах, приступають до масажу дельтоподібного, двоголового і триголового м'язів.

Перші сеанси масажу виконуються в тих вихідних положеннях, які хворий може приймати безболісно.

Спочатку масажується все плече. Виконуються поглажування, прийоми вичавлювання, розминання, поштовхи і знову поглажування. Кількість повторень прийомів буде залежати від перебігу відновного процесу. Після кількох сеансів загального масажу кінцівки приступають до масажу кожного м'яза окремо. Методика сеансів масажу повинна змінюватися в залежності від поставленого завдання. Наприклад, якщо $\epsilon$ труднощі у відведенні або розгинанні плеча, процедура будується так, щоб комплекс застосовуваних прийомів сприяв збільшенню амплітуди в цих напрямках. Надпліччя, плечовий суглоб і м'яз плеча можна масажувати до 3 разів на день. Можуть бути різні положення пацієнта: сидячи, лежачи на спині, лежачи на животі; масажист щоразу обирає найбільш зручний варіант [6].

На плечовому суглобі застосовуються різні прийоми розтирання. Після масажу плеча масажується ліктьовий суглоб і передпліччя. Застосовуються прийоми розтирання, вичавлювання і розминання. 
Висновки. Отже, масаж є важливим та дієвим методом фізичної терапії у процесі відновлення пацієнта після вивиху плечового суглоба. Застосування методик масажу $є$ ефективним при врахуванні усіх особливостей травми, методу лікування, стану пацієнта і етапу процесу відновлення. На кожному етапі відновного процесу повинні враховуватись особливості стану організму хворого i розроблятись відповідні йому схеми проведення масажних процедур. При урахуванні усіх зазначених особливостей, масаж буде ефективним засобом фізичної терапії а процес відновлення організму після травми менш тривалим і болісним.

\section{Jimepamypa:}

1. Cheatham S. W., Stull K. R., Ambler-Wright T. Roller massage: Survey of physical therapy professionals and a commentary on clinical standards-part II. International journal of sports physical therapy. 2018. Vol. 13. No. 5. P. 920.

2. Yeun Y. R. Effectiveness of massage therapy for shoulder pain: a systematic review and meta-analysis. Journal of physical therapy science. 2017. Vol. 29. No. 5. P. 936-940.

3. Kitisomprayoonkul W. Brachial plexus injury after massage: a case report. J Thai Rehabil Med. 2018. Vol. 28. No. 1. P. 21-23.

4. Kitagawa T., Matsui N., Nakaizumi D. Impact of combination of therapeutic exercise and psychological intervention for a patient with first-time traumatic shoulder dislocation //Journal of physical therapy science. 2019. Vol. 31. No.10. P.850-854.

5. Twain M. Musculoskeletal Pathologies, Disorders, and Injuries. Mosby's Pathology for Massage Professionals-E-Book. 2021. P. 114.

6. Li N. et al. Therapeutic effect of acupuncture and massage for shoulder-hand syndrome in hemiplegia patients: a clinical two-center randomized controlled trial. Journal of Traditional Chinese Medicine. 2012. Vol. 32. No.3. P.343-349.

7. Tsai W. S., Lee Y. C. Sequential changes to intraocular lens dislocation caused by vigorous ocular massage: A case report. Medicine. 2020. Vol. 99. No. 20. doi: 10.1097/MD.0000000000020069

8. Cheatham S. W., Stull K. R. Roller massage: A commentary on clinical standards and survey of physical therapy professionals-Part 1. International journal of sports physical therapy. 2018. Vol. 13. No. 4. P. 763.

\section{References:}

1. Cheatham, S. W., Stull, K. R., \& Ambler-Wright, T. (2018). Roller massage: Survey of physical therapy professionals and a commentary on clinical standards-part II. International journal of sports physical therapy, 13(5), 920.

2. Yeun, Y. R. (2017). Effectiveness of massage therapy for shoulder pain: a systematic review and meta-analysis. Journal of physical therapy science, 29(5), 936-940.

3.Kitisomprayoonkul, W. (2018). Brachial plexus injury after massage: a case report. $J$ Thai Rehabil Med, 28(1), 21-23.

4. Kitagawa, T., Matsui, N., \& Nakaizumi, D. (2019). Impact of combination of therapeutic exercise and psychological intervention for a patient with first-time traumatic shoulder dislocation. Journal of physical therapy science, 31(10), 850-854.

5. Twain, M. (2021). Musculoskeletal Pathologies, Disorders, and Injuries. Mosby's Pathology for Massage Professionals-E-Book, 114. 
6. Li, N., Tian, F., Wang, C., Yu, P., Zhou, X., Wen, Q., ... \& Huang, L. (2012). Therapeutic effect of acupuncture and massage for shoulder-hand syndrome in hemiplegia patients: a clinical two-center randomized controlled trial. Journal of Traditional Chinese Medicine, 32(3), 343-349.

7. Tsai, W. S., \& Lee, Y. C. (2020). Sequential changes to intraocular lens dislocation caused by vigorous ocular massage: A case report. Medicine, 99(20). doi: 10.1097/MD.0000000000020069

8. Cheatham, S. W., \& Stull, K. R. (2018). Roller massage: A commentary on clinical standards and survey of physical therapy professionals-Part 1. International journal of sports physical therapy, 13(4), 763. 